\title{
TU/e emonownen

\section{Money allocation to out-of-home leisure activities and the organization of these activities in time and space}

\section{Citation for published version (APA):}

Dane, G. Z., Arentze, T. A., Timmermans, H. J. P., \& Ettema, D. F. (2015). Money allocation to out-of-home leisure activities and the organization of these activities in time and space. International Journal of Sustainable Transport, 9(6), 398-404. https://doi.org/10.1080/15568318.2013.777259

DOI:

10.1080/15568318.2013.777259

Document status and date:

Published: 01/01/2015

\section{Document Version:}

Publisher's PDF, also known as Version of Record (includes final page, issue and volume numbers)

\section{Please check the document version of this publication:}

- A submitted manuscript is the version of the article upon submission and before peer-review. There can be important differences between the submitted version and the official published version of record. People interested in the research are advised to contact the author for the final version of the publication, or visit the $\mathrm{DOI}$ to the publisher's website.

- The final author version and the galley proof are versions of the publication after peer review.

- The final published version features the final layout of the paper including the volume, issue and page numbers.

Link to publication

\section{General rights}

Copyright and moral rights for the publications made accessible in the public portal are retained by the authors and/or other copyright owners and it is a condition of accessing publications that users recognise and abide by the legal requirements associated with these rights.

- Users may download and print one copy of any publication from the public portal for the purpose of private study or research.

- You may not further distribute the material or use it for any profit-making activity or commercial gain

- You may freely distribute the URL identifying the publication in the public portal.

If the publication is distributed under the terms of Article 25fa of the Dutch Copyright Act, indicated by the "Taverne" license above, please follow below link for the End User Agreement:

www.tue.nl/taverne

Take down policy

If you believe that this document breaches copyright please contact us at:

openaccess@tue.nl

providing details and we will investigate your claim. 


\title{
Money Allocation to Out-of-Home Leisure Activities and the Organization of These Activities in Time and Space
}

\author{
GAMZE DANE ${ }^{1}$, THEO A. ARENTZE ${ }^{1}$, HARRY J. P. TIMMERMANS ${ }^{1}$, and DICK ETTEMA ${ }^{2}$ \\ ${ }^{1}$ Urban Planning Group, Eindhoven University of Technology, Eindhoven, The Netherlands \\ ${ }^{2}$ Faculty of Geosciences, Utrecht University, Utrecht, The Netherlands
}

Received 4 February 2012, Revised 2 June 2012, Accepted 15 October 2012

\begin{abstract}
Monetary budgets influence activity participation and related travel as they demarcate limits on how people organize their activities in time and space. In this paper, we are interested in money allocation to out-of-home leisure activities and how this is affected by duration, sociodemographics, and time-location variables. Analyses were carried out by applying a seemingly unrelated regression model to a leisure activity data set. The analyses revealed that expenditures for out-of-home leisure activities are influenced by the variables mentioned above. Moreover, the results indicate that there is a substitution between expenditure of each activity.
\end{abstract}

Keywords: activity duration, activity-travel patterns, monetary expenditures, out-of-home leisure activity

\section{Introduction}

Activity-travel patterns shape urban settlements and vice versa. Understanding activity-travel patterns is therefore important to guide sustainable development. Since the mid-1990s, activitybased models have been developed to better represent the decision mechanisms of individuals and households. A distinctive feature of these models is their consideration of time expenditure on activities and travel for predicting activity-travel patterns in time and space.

In time-use studies of activity-travel behavior, it is assumed that spending time on activities brings utility. This utility can be explained with a concave function because utility increases with decreasing marginal utility. Moreover, time allocated to an activity is chosen to maximize the utility that is obtained, subject to the time constraint (Bhat and Misra 1999; Kitamura 1984). Therefore, these models can explain the influence of changes in urban structure and transportation by predicting the effects of these changes on activity participation and time allocation.

Activity participation is affected, however, not only by time constraints, but also by monetary constraints, because many activities require money, directly or indirectly. Moreover, growing scarce resources will likely increase the costs of conducting activities. Therefore, understanding the allocation of monetary budgets for different activities is important for shaping a better sustainable urban settlement.

The relation between time use and monetary expenditures is significant, especially for out-of-home leisure activities. For instance, if an individual spends more time on an activity, then this may increase monetary expenditure. There is also a

Address correspondence to Gamze Dane, Urban Planning Group, Eindhoven University of Technology, Eindhoven, The Netherlands. E-mail: g.z.dane@tue.nl trade-off between monetary expenditures and time use within activities. For example, if an individual has to spend more time on in-home activities, this decreases the time spent on out-ofhome activities.

The study of monetary constraints in activity participation started in the mid-1960s. Becker (1965) proposed a microeconomic framework addressing the importance of monetary constraints in activity participation. In his microeconomic framework, income was added as a constraint. Later, De Serpa (1971) and Evans (1972) proposed improvements and modifications of this seminal model. According to microeconomic theories, utility is a function of time spent on different activities and the consumption of goods during these activities, which is associated with the cost of the activity. Therefore, participation in an activity for a given duration implies a particular cost. Constraints are derived from time and money budgets for conducting various activities so that trade-offs have to be made between these budgets. However, this model does not consider spatial aspects, such as travel time, travel costs, and price differentiation between locations.

These early theories create the foundation for several recent studies on the subject of time and money constraints (e.g., Arentze and Timmermans 2011; Jara-Diaz et al. 2008; Kockelman 2001; Konduri et al. 2011; Zhang 2009). Except Arentze and Timmermans (2011) and Zhang (2009), these frameworks for modeling activity resource allocation do not consider allocation of monetary budgets on an activity episode level, but describe the total time allocated to activity classes across episodes. Although Zhang (2009) considers the allocation of budgets on an activity episode level, his framework ignores spatial elements and activity participation. Consequently, these frameworks cannot incorporate conditions and choice facets such as location and timing that may vary across episodes of an activity and hence influence duration and expenditure choices as well. In particular, monetary expenditures are also 
affected in two ways by where an activity is conducted. First, by spending more time or money on traveling, one can reach a more attractive location where one can likely spend more time and money. Second, the location may influence time and money spent directly if locations differ in terms of price levels. In addition, time variables such as season and day of the week influence activity participation. For instance, people engage in fewer water recreation activities during winter and more going-out activities on weekends. Moreover, individuals from different sociodemographic backgrounds may have different activity patterns. To address these issues, Arentze and Timmermans (2011) developed a random utility maximization (RUM) dynamic activity-based framework for simultaneous modeling time and money budget constraints on an activity episode level. However, this model has not been validated empirically yet.

In this paper, we are interested in the money allocation for outof-home leisure activities because the availability of out-of-home leisure activities is increasing rapidly, which causes more consumption of these activities and their related travel. Using seemingly unrelated regression analysis, the specific purpose of this paper is to estimate the effects of sociodemographics and time-location variables such as day of the week and location of activity on activity participation, taking into account the duration of out-of-home leisure activities. The specification of the analysis is derived from a utility-maximization model of activity participation under a monetary budget constraint. This paper reports estimation results based on a national continuous leisure time data set collected in 2008 in the Netherlands.

The paper is structured as follows. First, we introduce the methodology. Next, we present the data and estimation results. Finally, the paper concludes with a summary of results and a discussion of future research.

\section{Methodology}

Our utility function stems from the existing Cobb-Douglas production function (Cobb and Douglas 1928). The Cobb-Douglas functional form of production functions is widely used to represent the relationship between inputs and output. Moreover, it has also been used for activity time allocation models by Jara-Diaz et al. (2008) and Konduri et al. (2011). We can rewrite the function as a utility function that is derived from the attractiveness of time and location, time spent, and expenditure spent as in the following equation:

$$
U_{i j p}=A_{i j p}\left(T_{i j p}\right)^{\alpha_{i}}\left(E_{i j p}\right)^{\beta_{i}}
$$

where $i, j$, and $p$ are the subscripts for activity type, activity episode, and person; $U$ is the utility derived from conducting an activity; $A_{i j p}$ is a utility factor derived from the attractiveness of the location of the activity, the start time of the activity, the season, and the day of the week; $T_{i j p}$ is the duration; $E_{i j p}$ is the money spent on the activity; and $\alpha_{\mathrm{i}}$ and $\beta_{\mathrm{i}}$ are saturation parameters for duration and expenditure. The latter saturation parameters range between 0 and 1 . When the value of $\alpha_{\mathrm{i}}$ is smaller than one, the utility function displays diminishing returns with increasing duration of the activity episode, which is realistic for out-of-home leisure activities. Likewise, when the value of $\beta_{\mathrm{i}}$ is smaller than one, the utility function displays diminishing returns with increasing expenditure for the activity episode.

Expenditures for activities are constrained by the available monetary budget. Therefore, the marginal utility for expenditure is equal to a value that represents the budget constraint. For instance, if a marginal utility is high, this means that the budget constraint is tight because an individual with a low budget gets more satisfaction from conducting an activity. The marginal utility of expenditure is given by:

$$
\partial U_{i j p} / \partial E_{i j p}=\beta_{i} A_{i j p}\left(T_{i j p}\right)^{\alpha_{i}}\left(E_{i j p}\right)^{\beta_{i}-1}
$$

We can write marginal utility of expenditure $\partial U_{i j p} / \partial E_{i j p}$ as a constant $C$, which represents scarcity of money for each person. Equation 2 can be solved for expenditure and transformed to a logarithmic form to obtain an additive function. This results in the following equation:

$$
\ln \left(\mathrm{E}_{\mathrm{ijp}}\right)=\frac{1}{\beta_{\mathrm{i}}-1}\left(\ln \left(\mathrm{C}_{\mathrm{p}}\right)-\ln \left(\beta_{\mathrm{i}}\right)-\ln \left(\mathrm{A}_{\mathrm{ijp}}\right)-\alpha_{\mathrm{i}} \ln \left(\mathrm{T}_{\mathrm{ijp}}\right)\right)
$$

For convenience, we define:

$$
\mathrm{b}_{\mathrm{i}}=\frac{1}{\beta_{\mathrm{i}}-1}
$$

It should be noted that $b_{i}$ has a negative value because $\beta_{i}$ ranges between zero and one. Then Equation 3 can be rewritten as follows:

$$
\ln \left(E_{i j p}\right)=b_{i} \ln \left(C_{p}\right)-b_{i} \ln \left(\beta_{i}\right)-b_{i} \ln \left(A_{i j p}\right)-\alpha_{i} b_{i} \ln \left(T_{i j p}\right)
$$

For ease of estimation, we seek a function of expenditure that is linear in parameters. If we assume for ease that the second term is approximately a constant:

$$
\theta_{i} \approx b_{i} \ln \left(\beta_{i}\right)
$$

then we can rewrite Equation 5 as follows:

$$
\ln \left(E_{i j p}\right)=\theta_{i}+b_{i} \ln \left(C_{p}\right)-b_{i} \ln \left(A_{i j p}\right)-\alpha_{i} b_{i} \ln \left(T_{i j p}\right)
$$

The first two terms on the right-hand side of the equation represent a budget effect and an attractiveness effect on expenditure, respectively. To obtain a linear model, we specify these components as a linear function of a set of explanatory variables, as follows:

$$
\begin{aligned}
\mathrm{b}_{\mathrm{i}} \ln \left(\mathrm{C}_{\mathrm{p}}\right) & =\sum_{\mathrm{k}} \lambda_{\mathrm{ki}} \mathrm{X}_{\mathrm{kip}} \\
\mathrm{b}_{\mathrm{i}} \ln \left(\mathrm{A}_{\mathrm{ijp}}\right) & =\sum_{\mathrm{m}} \gamma_{\mathrm{mi}} \mathrm{Z}_{\mathrm{mjp}} \\
\alpha_{\mathrm{i}} \mathrm{b}_{\mathrm{i}} & =\delta_{\mathrm{i}}
\end{aligned}
$$

where $X$ are person/household level indicators of available budgets of each person conducting an activity, $Z$ are time and location level variables of attractiveness of the activity episode for each person, and $\lambda_{k i}$ and $\gamma_{m i}$ are parameters to be estimated. Person/household level indicators such as gender, age, etc., are 
used for marginal utility of expenditure because the sociodemographic variables in the model enable us to estimate possible systematic effects of these person variables on the utility. The last component $\delta_{i}$, represents the effect of duration of the activity type on expenditure. Finally, we get the following linear-in-parameters function for expenditure, which is a regression model of monetary allocation:

$$
\ln \left(E_{i j p}\right)=\theta_{i}+\sum_{k} \lambda_{k i} X_{k i p}-\sum_{m} \gamma_{m i} Z_{m j p}-\delta_{i} \ln \left(T_{i j p}\right)
$$

Because the proposed model is a linear-in-parameters equation (11), we can apply a seemingly unrelated regression estimation (SURE) to test the impact of various sociodemographic, time-location variables and duration effects, in which the impact of those variables are estimated simultaneously on different activity expenditures. The model can be estimated equation-by-equation using the standard ordinary least squares (OLS) method. However, these estimates are not as efficient as the SURE method, which uses a feasible generalized least squares criterion with a specific form of the variancecovariance matrix (Zellner 1962). The SURE system assumes that the error terms are correlated across the equations and therefore the equations are related to each other. First, we assume that a utility is derived from an activity $i$, which consists of an error term. Therefore, we can use Equation 12 to have a system of simultaneous equations for each activity category.

$$
\ln \left(E_{i j p}\right)=\theta_{i}+\sum_{k i} \lambda_{k i} X_{k i p}-\sum_{m i} \gamma_{m i} Z_{m j p}-\delta_{i} \ln \left(T_{i j p}\right)+\varepsilon_{i j p}
$$

This system can be estimated as a system of seemingly unrelated regressions, allowing the error terms $\varepsilon_{i j p}$ to be correlated to represent mutual dependencies between activity types.

\section{Data}

The data used for the empirical analysis in the paper was obtained from the 2008/2009 Continuous Free Time Use (CVTO) data set. CVTO is a national-level survey conducted by the Dutch Board of Tourism and Conventions and Taylor Nelson Sofres-Netherlands Institute for Public Opinion (TNSNIPO). It is representative of the Dutch population, conducted between May 2008 and May 2009. The data set includes information about expenditures for various kinds of activities (direct costs of activity), such as consumptions during the activity, entrance fee, money spent in the shops, etc., and the expenditure of travel for these activities. The data do not include subscription, contribution, and membership costs.

This survey collected information on leisure activity episodes that the individual participated in over the course of a week. Only the activities that were conducted for one hour or more are included in the data set. A wide range of activities were collected that can be clustered into 10 activities as follows:

- Outdoor recreation, such as walking for pleasure or recreation in parks, forests, or near the sea

\begin{tabular}{|c|c|c|}
\hline Variables & Frequency & Percent \\
\hline \multicolumn{3}{|c|}{ Sociodemographic Variables } \\
\hline \multicolumn{3}{|c|}{ Gender } \\
\hline Male & 4925 & 47.4 \\
\hline Female & 5472 & 521.6 \\
\hline \multicolumn{3}{|l|}{ Age } \\
\hline$<18$ & 1590 & 15.3 \\
\hline $18-24$ & 819 & 7.9 \\
\hline $25-54$ & 4974 & 47.8 \\
\hline $55-64$ & 1485 & 14.3 \\
\hline $65-74$ & 1057 & 10.2 \\
\hline$>75$ & 472 & 4.5 \\
\hline \multicolumn{3}{|l|}{ Social Class } \\
\hline High & 1863 & 17.9 \\
\hline Middle & 5985 & 57.6 \\
\hline Low & 2549 & 24.5 \\
\hline \multicolumn{3}{|l|}{ Household Composition } \\
\hline Single & 1761 & 17.0 \\
\hline Family with children & 5514 & 53.0 \\
\hline Family without & & \\
\hline children & 3122 & 30.0 \\
\hline \multicolumn{3}{|l|}{ Urban Density } \\
\hline Strong & 4940 & 47.5 \\
\hline Moderate & 2488 & 23.9 \\
\hline Low & 2969 & 28.6 \\
\hline \multicolumn{3}{|c|}{ Time \& Location Variables } \\
\hline \multicolumn{3}{|c|}{ Season } \\
\hline Summer & 2459 & 23.7 \\
\hline Other seasons & 7938 & 76.3 \\
\hline \multicolumn{3}{|l|}{ Day of the Week } \\
\hline Weekdays & 5795 & 55.7 \\
\hline Weekends & 4602 & 44.3 \\
\hline \multicolumn{3}{|l|}{ Start Time } \\
\hline Morning & 3675 & 35.3 \\
\hline Afternoon & 4395 & 42.3 \\
\hline Evening and night & 2327 & 22.4 \\
\hline \multicolumn{3}{|l|}{ Location } \\
\hline City/village center & 9411 & 90.5 \\
\hline City park & 63 & 0.6 \\
\hline On or near water & 234 & 2.3 \\
\hline Own neighborhood & 88 & 0.8 \\
\hline Rural or recreational & 494 & 4.8 \\
\hline Other areas & 107 & 1.0 \\
\hline \multicolumn{3}{|l|}{ Activities } \\
\hline \multicolumn{3}{|l|}{ Activity Purpose } \\
\hline Outside recreation & 1490 & 14.3 \\
\hline Water recreation & 529 & 4.1 \\
\hline Visiting sport event & 337 & 3.2 \\
\hline Wellness and beauty & 261 & 2.5 \\
\hline Attraction visit & 725 & 7.0 \\
\hline Event visit & 432 & 4.2 \\
\hline Fun shopping & 3078 & 29.6 \\
\hline Culture & 495 & 4.8 \\
\hline Going out & 1919 & 18.5 \\
\hline \multicolumn{3}{|l|}{ Other hobbies and } \\
\hline courses & 1131 & 10.9 \\
\hline
\end{tabular}

Table 1. Sample characteristics 
- Water recreation and sports such as surfing, fishing, swimming

- Event visits such as exhibition, fairs, shows, festivals

- Fun shopping (doesn't include grocery shopping) such as shopping for pleasure in the shopping center, furniture mall visit, going to factory outlet

- Culture such as concert, musical, museum

- Visiting sports events such as going to watch a football game

- Attraction visit such as attraction parks, zoo

- Going out such as bar, café, disco visits, eating out

- Wellness and beauty

- Other hobbies and courses such as club activities, drawing, taking photographs, language courses

The episode-level information collected in the data set includes the kind of activity, start time, duration of the activity and travel, expenditure for the activity and travel, location of the activity, and travel distance to the activity. In addition, data on individual and household sociodemographics are collected.

Table 1 gives an overview of the key sample characteristics. The sample is fairly distributed across gender classes. $47.8 \%$ of the sample is between 25 and 54 years of age. $57.6 \%$ of the sample is from the middle social class. $53.0 \%$ of the households are families with children and the rest are single households and families without children. Almost half of the sample lives in strong urban density areas. When we look at time and location variables, activities conducted in summer represent $23.7 \%$ of the sample. $55.7 \%$ are out-of-home leisure activities conducted on weekdays, while $44.3 \%$ are conducted on weekends. $35.3 \%$ of the activities begin in the morning; $42.3 \%$ start in the afternoon, and $22.4 \%$ begin in the evening. Most activities are conducted in a city or village center. Fun shopping is the most frequently conducted activity with a percentage of $29.6 \%$, followed by going out and outside recreation.

\section{Empirical Analysis}

\subsection{Variable Specification}

The data set has a panel structure because each respondent does more than one activity in a week and so has multiple responses. To eliminate the panel structure, we randomly sampled one activity of each person. Several types of variables were considered in the model specification. These included (1) total duration of the activity and travel; (2) individual and household sociodemographics (gender, age, social class, household composition, and urban density); (3) timing and location variables (day of the week and season of the year, beginning time of activity, location, distance to the activity); and (4) activity type that is conducted. The dependent variable is total expenditure on activity and travel. We used the natural logarithm of expenditure in the regression and therefore the activities that have no expenditure were excluded. Moreover, we also used the natural logarithm of duration in the regression. Expenditure, distance, and total duration variables are used as continuous variables in the regression, while the others were coded as dummy variables.

In the data set, most activities $(90.5 \%)$ are conducted in a city/village center. Table 2 shows the observed frequencies of location types for each activity. Outside recreation and water recreation activities are observed in different location categories, while other activities are observed only in the city/ village center. Therefore, location type will be used only in the models for outside recreation and water recreation activities.

\subsection{Model Estimation Results}

Tables 3.1 and 3.2 present the model estimation results. An empty cell in this table indicates that the variable does not have a statistically significant effect on the activity. The coefficients in the table indicate the effects of variables on expenditures for activities. A positive sign of an estimated coefficient indicates that either the budget is greater or that the attractiveness of the location or time of the activity is greater. This reflects the tendency that expenditure increases both if the budget is greater and the attractiveness is greater. It is noted, however, that with this regression analysis we cannot disentangle the budget effect and attraction effect on expenditure. Furthermore, the estimates capture an effect of $\beta$, which is a saturation effect. For instance, people with higher saturation, that is, who experience more strongly diminishing returns on expenditure, will spend less. Overall, the coefficients that are estimated cannot separate budget effects, attraction effects, and saturation effects.

If we look at the sociodemographic effects on activities, we see that being female has a positive effect on expenditures for wellness and beauty, event visits, and fun shopping activities, while it has a negative effect on expenditures for outside recreation, visiting a sports event, and going-out activities. People less than 18 years of age have a positive effect on expenditure for water recreation and attraction visit. However, people less than 18 years of age have a negative effect on fun shopping

Table 2. Observed leisure out-of-home activities according to the location types

\begin{tabular}{|c|c|c|c|c|c|c|c|c|c|c|c|}
\hline & $\begin{array}{l}\text { Outside } \\
\text { recreation }\end{array}$ & $\begin{array}{l}\text { Water } \\
\text { recreation }\end{array}$ & $\begin{array}{l}\text { Visiting } \\
\text { sport } \\
\text { event }\end{array}$ & $\begin{array}{l}\text { Wellness } \\
\text { and } \\
\text { beauty }\end{array}$ & $\begin{array}{l}\text { Attraction } \\
\text { visit }\end{array}$ & $\begin{array}{c}\text { Event } \\
\text { visit }\end{array}$ & $\begin{array}{c}\text { Fun } \\
\text { shopping }\end{array}$ & Culture & $\begin{array}{l}\text { Going } \\
\text { out }\end{array}$ & $\begin{array}{c}\text { Other } \\
\text { hobbies } \\
\text { and courses }\end{array}$ & Total \\
\hline City/village center & 580 & 453 & 337 & 261 & 725 & 432 & 3078 & 495 & 1919 & 1131 & 9411 \\
\hline City park & 59 & 4 & 0 & 0 & 0 & 0 & 0 & 0 & 0 & 0 & 63 \\
\hline On or near water & 186 & 48 & 0 & 0 & 0 & 0 & 0 & 0 & 0 & 0 & 234 \\
\hline Own neighborhood & 83 & 5 & 0 & 0 & 0 & 0 & 0 & 0 & 0 & 0 & 88 \\
\hline Rural or recreational & 484 & 10 & 0 & 0 & 0 & 0 & 0 & 0 & 0 & 0 & 494 \\
\hline Other areas & 98 & 9 & 0 & 0 & 0 & 0 & 0 & 0 & 0 & 0 & 107 \\
\hline Total & 1490 & 529 & 344 & 261 & 725 & 433 & 3078 & 495 & 1919 & 1166 & 10397 \\
\hline
\end{tabular}


Table 3.1. Estimation results

\begin{tabular}{|c|c|c|c|c|c|c|c|c|c|c|c|}
\hline \multirow{2}{*}{\multicolumn{2}{|c|}{ Activities/Main effects }} & \multicolumn{2}{|c|}{$\begin{array}{l}\text { Outside } \\
\text { recreation }\end{array}$} & \multicolumn{2}{|c|}{$\begin{array}{l}\text { Water } \\
\text { recreation }\end{array}$} & \multicolumn{2}{|c|}{$\begin{array}{l}\text { Visiting sport } \\
\text { event }\end{array}$} & \multicolumn{2}{|c|}{$\begin{array}{l}\text { Wellness } \\
\text { and beauty }\end{array}$} & \multicolumn{2}{|c|}{$\begin{array}{l}\text { Attraction } \\
\text { visit }\end{array}$} \\
\hline & & $B$ & Sig. & $B$ & Sig. & $B$ & Sig. & $B$ & Sig. & $B$ & Sig. \\
\hline \multirow{3}{*}{$\begin{array}{l}\text { Constant } \\
\text { Gender } \\
\text { Age }\end{array}$} & & 0.73 & 0.00 & & & -0.19 & 0.00 & & & -0.42 & 0.00 \\
\hline & Female & -0.01 & 0.03 & & & -0.02 & 0.00 & 0.02 & 0.00 & & \\
\hline & $\begin{array}{l}<18 \\
25-54 \\
55-64 \\
65-74 \\
75+\end{array}$ & $\begin{array}{l}0.04 \\
0.04\end{array}$ & $\begin{array}{l}0.01 \\
0.01\end{array}$ & 0.03 & 0.00 & & & & & 0.03 & 0.01 \\
\hline Social Class & $\begin{array}{l}\text { High } \\
\text { Middle }\end{array}$ & & & -0.01 & 0.01 & -0.01 & 0.04 & & & & \\
\hline Household & $\begin{array}{l}\text { Single } \\
\text { Family without children }\end{array}$ & 0.02 & 0.01 & & & $\begin{array}{l}-0.01 \\
-0.01\end{array}$ & $\begin{array}{l}0.03 \\
0.01\end{array}$ & 0.02 & 0.00 & $\begin{array}{l}-0.02 \\
-0.02\end{array}$ & $\begin{array}{l}0.05 \\
0.02\end{array}$ \\
\hline Urban Density & $\begin{array}{l}\text { Strong } \\
\text { Moderate }\end{array}$ & & & -0.01 & 0.04 & & & & & & \\
\hline Season & Summer & 0.03 & 0.00 & & & -0.01 & 0.00 & & & 0.02 & 0.00 \\
\hline Day of the Week & Weekends & 0.04 & 0.00 & -0.02 & 0.00 & 0.03 & 0.00 & -0.02 & 0.00 & 0.01 & 0.01 \\
\hline Beginning Time & $\begin{array}{l}\text { Morning } \\
\text { Afternoon }\end{array}$ & $\begin{array}{l}0.03 \\
0.04\end{array}$ & $\begin{array}{l}0.00 \\
0.00\end{array}$ & 0.02 & 0.00 & -0.01 & 0.05 & & & $\begin{array}{l}0.05 \\
0.02\end{array}$ & $\begin{array}{l}0.00 \\
0.02\end{array}$ \\
\hline Distance & & 0.0035 & 0.00 & & & & & & & 0.0006 & 0.00 \\
\hline \multirow[t]{5}{*}{ Location } & City park & 0.12 & 0.00 & -0.04 & 0.05 & - & - & - & - & - & - \\
\hline & On or near Water & 0.29 & 0.00 & 0.10 & 0.00 & - & - & - & - & - & - \\
\hline & Own neighborhood & 0.11 & 0.01 & & & - & - & - & - & - & - \\
\hline & Rural or recreational & 0.25 & 0.00 & & & - & - & - & - & - & - \\
\hline & Other areas & 0.17 & 0.00 & -0.05 & 0.00 & - & - & - & - & - & - \\
\hline \multirow{2}{*}{\multicolumn{2}{|c|}{$\begin{array}{l}\text { Duration } \\
\text { R-square }\end{array}$}} & 0.08 & 0.00 & & & 0.04 & 0.00 & & & 0.10 & 0.00 \\
\hline & & \multicolumn{2}{|c|}{0.144} & \multicolumn{2}{|c|}{0.018} & & & \multicolumn{2}{|c|}{0.011} & 0.03 & \\
\hline
\end{tabular}

and going-out activities. This is an expected result due to the limited monetary budget of this age category. Moreover, people between the ages of 25 and 54 tend to spend less on going-out activities compared to the base category. Furthermore, people between the ages of 55 and 64 tend to spend more on outside recreation and other hobbies, while they tend to spend less on fun shopping and going-out activities. It is also found that people between the ages of 65 and 74 have a positive effect on expenditure for outside recreation and other hobbies and they have a negative effect on expenditure for fun shopping and going-out activities. In addition to this, it is found that people over the age of 75 have a positive effect on expenditure for culture and other hobbies, while they have a negative effect on expenditure for fun shopping and going-out activities. These results indicate that the need for fun shopping and going-out activities decreases with aging.

People from high social classes tend to spend more on event visits, culture, and going-out activities, while they tend to spend less on visiting sports events and fun shopping activities. Moreover, the middle social class has a positive effect on expenditure for event visits and culture activities; however, it has a negative effect on water recreation and fun shopping activities. The results show that people spend more on event visits and culture activities with increasing social class, which is expected. Another result indicates that expenditure on fun shopping increases with increasing social class.

Furthermore, when we look at the household composition effects, it is found that single households tend to spend more on wellness and beauty and going-out activities. However, they tend to spend less on visiting sports events and attraction visit activities. It is also found that families without children have a positive effect on the expenditure for outside recreation, fun shopping, and going-out activities, while they have a negative effect on visiting sports events and attraction visits.

Strong urban density has a positive effect on expenditure for fun shopping and culture activities, while it has a negative effect on expenditure for event visits and other hobbies. Moderate urban density has a negative effect on expenditure for water recreation activities. This might be a result of a correlation between the type of water recreation activity (less expensive) and urban density (moderate) of the location where it is conducted.

With respect to the time variables, summer has a positive effect on expenditure for outside recreation, attraction visits, and going-out activities. This result is expected because those activities are conducted mostly when the weather is suitable. Moreover, summer has a negative effect on visiting sports event activities, which is also expected because sports events are not conducted during the summer as often as other seasons. In addition, summer also has a negative effect on expenditure on other hobbies. Furthermore, weekend has a positive effect on expenditure for outside recreation, visiting sports events, attraction visits, event visits, and going-out activities, while it has a negative effect on water recreation, wellness and beauty, fun shopping, and other hobbies. Conducting activities in the morning has a positive effect on expenditure for outside 
Table 3.2. Estimation results

\begin{tabular}{|c|c|c|c|c|c|c|c|c|c|c|c|}
\hline \multirow{2}{*}{\multicolumn{2}{|c|}{ Activities/Main effects }} & \multicolumn{2}{|c|}{ Event visit } & \multicolumn{2}{|c|}{ Fun shopping } & \multicolumn{2}{|c|}{ Culture } & \multicolumn{2}{|c|}{ Going out } & \multicolumn{2}{|c|}{ Other hobbies } \\
\hline & & $B$ & Sig. & $B$ & Sig. & $B$ & Sig. & $B$ & Sig. & $B$ & Sig. \\
\hline \multicolumn{2}{|l|}{ Constant } & -0.53 & 0.00 & 1.50 & 0.00 & -0.36 & 0.00 & -0.44 & 0.00 & & \\
\hline Gender & Female & 0.01 & 0.05 & 0.12 & 0.00 & & & -0.03 & 0.00 & & \\
\hline \multirow[t]{5}{*}{ Age } & $<18$ & & & -0.23 & 0.00 & & & -0.14 & 0.00 & & \\
\hline & $25-54$ & & & & & & & -0.07 & 0.00 & & \\
\hline & $55-64$ & & & -0.10 & 0.00 & & & -0.07 & 0.00 & 0.03 & 0.03 \\
\hline & $65-74$ & & & -0.14 & 0.00 & & & -0.13 & 0.00 & 0.03 & 0.01 \\
\hline & $75+$ & & & -0.10 & 0.01 & 0.05 & 0.00 & -0.07 & 0.03 & 0.04 & 0.01 \\
\hline \multirow[t]{2}{*}{ Social Class } & High & 0.02 & 0.03 & -0.07 & 0.00 & 0.02 & 0.00 & 0.04 & 0.01 & & \\
\hline & Middle & 0.01 & 0.04 & -0.06 & 0.00 & 0.02 & 0.00 & & & & \\
\hline \multirow[t]{2}{*}{ Household } & Single & & & & & & & 0.07 & 0.00 & & \\
\hline & Family without children & & & 0.05 & 0.01 & & & 0.03 & 0.01 & & \\
\hline Urban Density & $\begin{array}{l}\text { Strong } \\
\text { Moderate }\end{array}$ & -0.01 & 0.02 & 0.03 & 0.03 & 0.02 & 0.00 & & & -0.01 & 0.05 \\
\hline Season & Summer & & & & & & & 0.04 & 0.00 & -0.01 & 0.04 \\
\hline Day of the Week & Weekends & 0.02 & 0.00 & -0.05 & 0.00 & & & 0.09 & 0.00 & -0.02 & 0.00 \\
\hline \multirow[t]{2}{*}{ Beginning Time } & Morning & -0.02 & 0.01 & 0.38 & 0.00 & -0.09 & 0.00 & -0.32 & 0.00 & -0.02 & 0.00 \\
\hline & Afternoon & & & 0.37 & 0.00 & -0.07 & 0.00 & -0.19 & 0.00 & -0.04 & 0.00 \\
\hline Distance & & 0.0012 & 0.00 & -0.0010 & 0.00 & 0.0004 & 0.01 & 0.0021 & 0.00 & 0.0008 & 0.00 \\
\hline \multirow[t]{5}{*}{ Location } & City park & - & - & - & - & - & - & - & - & - & - \\
\hline & On or near water & - & - & - & - & - & - & - & - & - & - \\
\hline & Own neighborhood & - & - & - & - & - & - & - & - & - & - \\
\hline & Rural or recreational & - & - & - & - & - & - & - & - & - & - \\
\hline & Other areas & - & - & - & - & - & - & - & - & - & - \\
\hline \multicolumn{2}{|l|}{ Duration } & 0.11 & 0.00 & -0.20 & 0.00 & 0.09 & 0.00 & 0.09 & 0.00 & 0.03 & 0.00 \\
\hline \multicolumn{2}{|l|}{ R-square } & \multicolumn{2}{|c|}{0.043} & \multicolumn{2}{|c|}{0.075} & \multicolumn{2}{|c|}{0.032} & \multicolumn{2}{|c|}{0.075} & \multicolumn{2}{|c|}{0.014} \\
\hline
\end{tabular}

recreation, water recreation, attraction visits, and fun shopping, while it has a negative effect on event visits, culture, visiting sports events, going out, and other hobbies. Moreover, afternoon has a positive effect on expenditure on outside recreation, attraction visits, and fun shopping; however, it has a negative effect on culture, going out, and other hobbies. The likely explanation is that these activities are generally conducted in the evening instead of the morning or afternoon because culture, event visits, and courses generally take place in the evening. Moreover, going-out activities are mostly conducted in the evening.

Regarding location variables, the results indicate that outside recreation, attraction visits, event visits, culture, going out, and other hobbies have a positive effect on expenditure with increasing distance. However, distance has a negative effect on fun shopping activities, which could indicate that this activity is more attractive in closer locations or that people trade off between travel costs and money spent on shopping. Locationtype variables are estimated only for outside recreation and water recreation activities. City parks have a positive effect on outside recreation activities, while they have a negative effect on water recreation activities. Moreover, on or near water variables have a positive effect on outside recreation and water recreation activities. Own neighborhood and rural and recreational areas both have a positive effect on outside recreation activity.

Table 4. Covariance matrix

\begin{tabular}{|c|c|c|c|c|c|c|c|c|c|c|}
\hline & $\begin{array}{l}\text { Outside } \\
\text { recreation }\end{array}$ & $\begin{array}{c}\text { Water } \\
\text { recreation }\end{array}$ & $\begin{array}{c}\text { Visiting sport } \\
\text { event }\end{array}$ & $\begin{array}{l}\text { Wellness and } \\
\text { beauty }\end{array}$ & $\begin{array}{l}\text { Attraction } \\
\text { visit }\end{array}$ & $\begin{array}{l}\text { Event } \\
\text { visit }\end{array}$ & $\begin{array}{c}\text { Fun } \\
\text { shopping }\end{array}$ & Culture & $\begin{array}{l}\text { Going } \\
\text { out }\end{array}$ & $\begin{array}{c}\text { Other } \\
\text { hobbies }\end{array}$ \\
\hline Outside Recreation & 0.429 & -0.012 & -0.010 & -0.008 & -0.030 & -0.030 & -0.100 & -0.020 & -0.077 & -0.017 \\
\hline Water Recreation & & 0.130 & -0.002 & -0.003 & -0.007 & -0.004 & -0.039 & -0.004 & -0.017 & -0.004 \\
\hline Visiting Sport Event & & & 0.110 & -0.002 & -0.007 & -0.007 & -0.026 & -0.006 & -0.024 & -0.004 \\
\hline Wellness and Beauty & & & & 0.203 & -0.005 & -0.005 & -0.050 & -0.007 & -0.026 & -0.006 \\
\hline Attraction Visit & & & & & 0.290 & -0.018 & -0.070 & -0.012 & -0.043 & -0.010 \\
\hline Event Visit & & & & & & 0.263 & -0.049 & -0.015 & -0.051 & -0.011 \\
\hline Fun Shopping & & & & & & & 1.920 & -0.046 & -0.239 & -0.048 \\
\hline Culture & & & & & & & & 0.284 & -0.064 & -0.012 \\
\hline Going Out & & & & & & & & & 1.052 & -0.041 \\
\hline Other Hobbies & & & & & & & & & & 0.285 \\
\hline
\end{tabular}


Finally, the other areas variable has a positive effect on outside recreation, while it has a negative effect on the water recreation activities. All location variables have plausible and expected effects on outside recreation and water recreation activities.

Duration has a positive effect on expenditure for activities such as outside recreation, sports event visits, attraction visits, event visits, culture, going out, and other hobbies. This is the result of the relation between expenditure and duration for out-of-home leisure activities, which suggests that if more time is spent on an activity, then it is likely that more money will be spent on that activity. However, duration has a negative effect on fun shopping activity. This might reflect that fun shopping activity is a different type of activity in that expenditure is related to buying goods rather than nondurable consumptions. The effect suggests that more expensive purchases do not necessarily involve longer duration for activities.

A final finding about these estimates is the covariances between the error terms shown in Table 4. These can be interpreted to mean that a negative covariance implies that there is a substitution between expenditures of activities, while a positive covariance implies that expenditure on one activity results in expenditure on another activity (Ettema 2009). Table 4 shows that there is a substitution between all activities.

\section{Conclusion}

People conduct their activities under budget constraints that concern time and money. It is important to understand these constraints as they shape the set of feasible configurations of activity-travel patterns, which in turn affect the evolution and sustainability of urban environments. The aim of this paper is to contribute to this literature with an empirical study.

In this study, a linear-in-parameters regression model was derived from a utility-maximization model of activity participation under monetary budget constraints. Analyses were carried out by applying a seemingly unrelated regression model to a $2008 / 2009$ leisure activity data set. The analyses revealed that expenditures for out-of-home leisure activities are influenced by the duration of the activity and travel. This result was assumed by our modeling framework. With increasing duration of the leisure activity and travel, the expenditures increase, except fun shopping activity, which shows that fun shopping is a different kind of activity than other out-of-home leisure activities. Moreover, sociodemographic variables and time-location variables influence expenditures. Another result is that there is a substitution of expenditure between the out-of-home leisure activities.

This study provides insights into the relationships between monetary expenditures and duration, activity types, sociodemographic variables, and time-location variables. In turn, these activity-travel patterns influence the sustainability of the built environment. Time and money constraints affect the intensity and kind of activity participation that individuals and households can realize in any space-time setting. Time and money budgets can restrict or even prohibit people's opportunities to become engaged in activities they prefer to do or even worse prevent them from engaging in these activities and therefore induce social exclusion. In this case, the urban environment, in combination with the transport environment, is not very sustainable from both an economic and social perspective. However, further work is needed to understand how the trade-offs between time and monetary budgets are made and how available income and fixed expenditures affect the expenditures on out-of-home leisure activities and travel. Therefore, dedicated data collection is needed to further research this problem.

In addition to the general relationships between activitytravel patterns and expenditures, findings of this study also emphasize the role of particular location variables in stimulating out-of-home leisure activities. In particular, it is found that city parks are important for outside recreation activities. Furthermore, distance to the activity location has an effect on expenditure. With increasing distance, the expenditure on most out-of-home leisure activities increases as well (the only exception is fun shopping). This indicates that individuals generally can find more attractive locations for leisure activities by traveling farther and this affects the amount of expenditure for the activities. This suggests that the distance and location of activities, factors that are related to monetary expenditures, can be affected by applying transport pricing policies for a more sustainable environment.

\section{References}

Arentze T, Timmermans HJP. 2011. A dynamic model of time-budget and activity generation: Development and empirical derivation. Transportation Research Part C 19:242-253.

Becker G. 1965. A theory of the allocation of time. Economic Journal 75:493-517.

Bhat CR, Misra R. 1999. Discretionary activity time allocation of individuals between in-home and out-of-home and between weekdays and weekends. Transportation 26:193-209.

Cobb CW, Douglas PH. 1928. A theory of production. The American Economic Review 18:139-165.

De Serpa AC. 1971. A theory of the economics of time. The Economic Journal 81:828-846.

Ettema D. 2009. Travel, activities and money: An exploration of households' expenditures to travel, communication and facilities. Paper presented at the Transportation Research Board 88th Annual Meeting, 11-15 January, Washington DC.

Evans A. 1972. On the theory of the valuation and allocation of time. Scottish Journal of Political Economy 2:1-17.

Jara-Diaz SR, Munizaga MA, Greeven P, Guerra R, Axhausen K. 2008. Estimating the value of leisure from a time allocation model. Transportation Research Part B 42:946-957.

Kitamura R. 1984. A model of daily time allocation to discretionary out-of-home activities and trips. Transportation Research Part B $18: 255-266$.

Kockelman KM. 2001. A model for time and budget constrained activity demand analysis. Transportation Research Part B 35 (3):255-269.

Konduri KC, Tagle SA, Bhargava S, Pendyala RM, Jara-Diaz S. 2011. A joint analysis of time use and consumer expenditure data: An examination of two alternative approaches deriving values of time. Paper presented at the Transportation Research Board 90th Annual Meeting, 23-27 January, Washington DC.

Zellner A. 1962. An efficient method of estimating seemingly unrelated regression equations and tests for aggregation bias. Journal of the American Statistical Association 57:348-368.

Zhang Y. 2009. A model of time use and expenditure of pedestrians in the city centers. In: Timmermans H (ed.), Pedestrian Behavior, Models, Data Collection and Applications. Bingley, UK: Emerald Group Publishing, pp. 157-189. 